\title{
鉄道事業の自然災害リスク・ファイナンス における破産確率
}

\author{
大堀 勝正 1 森地 茂 2 \\ 1正会員＼cjkstart運輸政策研究機構＼cjkstart運輸政策研究所（†105-0001 東京都港区虎ノ門3-18-19） \\ E-mail: oohori@jterc.or.jp \\ 2名誉会員 政策研究大学院大学 政策研究センター所長（†106-8677 東京都港区六本木7-22-1） \\ E-mail: smorichi.pl@grips.ac.jp
}

\begin{abstract}
自然災害による損害発生には不確実性と大きな金額変動があるため，被災に備えるべき復旧資金は既往 最大または想定最大の災害を前提とした工学的分析を基に算出することが通常である。しかしながら, 経 営が厳しい鉄道事業者では想定最大災害に十分な資金調達は経営的に困難であり，発生頻度が比較的に多 い既往災害規模に対して支払不可能とならない程度に資金調達を行いたいというニーズが圧倒的に多い。 本研究では，そうした現場ニーズに応えるため鉄道各社の災害特性と財務状況を考慮した収支モデルを考 案し，被災実績データから推定された損害金額に対して来年度等の手元資金や保険などの資金調達を数理 的に分析するための破産確率モデルを示す.さらに，その統計的根拠を実証的に示す.
\end{abstract}

Key Words : railway business, natural disaster, risk finance, ruin probability, statistical evidence

\section{1. はじめに}

豪雨や地震など自然災害が多い日本では，毎年，全国 各地で被害が発生している. 膨大なインフラを保有する インフラ事業者は，自然災害による被害が甚大となり復 旧資金を調達できない場合，破産ひいては廃業となり， 社会経済に多大な影響を与える.これを回避するために, リスク・ファイナンスと称するさまざまな資金調達を講 じる必要がある.このことは存亡に係る重要な経営課題 であるが，交通インフラ事業においては，その資金対策 の実施率が低い状況にある1). 交通インフラ事業の中で も民営で独立採算を前提とした鉄道事業では，公的補助 や保険等の制度的課題もあり 2)，自然災害復旧の資金調 達に困窮している実態が報告されている1,33,4).

自然災害が契機となって廃止された鉄道は，確認でき たものだけでも30事例あり，1950～1987年度では年平均 0.68路線，1950〜2014年度では年平均0.45路線が自然災害 を契機に廃止に至っている（図-1）。近年では，第三セ クターの高千穂鉄道は2005年の台風14号により甚大な被 害を受けたが，保険に入り，国と自治体の補助制度があ ったにもかかわらず，災害復旧費に対する自己負担分の 償還見通しが立たず廃業に追い込まれた。自然災害は地 球温暖化等の要因もあり世界的に増加傾向にあるが，経 営状況が厳しい地方の中小民鉄や第三セクタ一鉄道等に
とって災害復旧の資金調達は非常に重要な経営課題であ る.こうした課題に対して，大堀51自然災害に対して 鉄道事業者が資金調達を安定的に行うための数理分析に おいて中核的機能を果たす破産確率を提案し，その活用 方法の概要を実証分析例を基に提案した。

本論は，こうした問題意識の下に，鉄道事業における 自然災害復旧に係る破産確率の数理モデルを示すととも に，自然災害による被災実績データに基づいて統計的根 拠を示すことを目的とするものである.

災害復旧のために投資までして存続する必要はないと 判断している鉄道事業者にとって，事前の資金対策を必 要としていないという議論もあり得るが，本論で対象と する鉄道は，地域の通勤・通学・観光振興等で必要とさ れており，被災に備えた資金対策の重要性が高いことを 前提としている.

以下，2.において鉄道事業における自然災害ならびに 関連研究に対する本研究の基本的立場について言及する. 3.では破産確率の数理モデルとその数理的根拠を示す. 4.では全国の第三セクター鉄道の自然災害実績データに 基づいて損害総額に係る確率分布を実証的に分析する. 5.で結論をとりまとめる. 


\section{2. 関連研究と本研究の基本的立場}

\section{（1）鉄道事業における自然災害の概要}

鉄道事業における自然災害の多くは，風水害と地震・ 津波に大別することができる（表-1）。図-1 と表-1 に 示寸実績から鉄道事業に甚大な被害をもたらす自然災害 の特徵として次の点を把握することができる.

- 風水害 : 地震・津波の比率は, 損害件数で概称 $9: 1$ である.たとえば，路線廃止の契機となった自然災害 のうち風水害が $90 \%$ で地震・津波が 10\%であり（図 -1），全国の第三セクター鉄道が 1991〜2012 年に被 った自然災害のうち風水害が 92\%で地震・津波が 8\%であり (表-1)，この両者はほぼ符合している.

- 鉄道構造物に甚大な被害をもたらす大規模な地震・津 波は，数十年間隔で発生している.

さらに，近年の自然災害種別の傾向について，JRの 鉄道構造物を対象に調査した太田・杉山 のは図-2などの 災害実績を基に主に次の 2 点を指摘している.

・切土の崩壊・変状が全体の約 3割を占める期間が続い ていたが，切土のり面対策が進んできたことにより 低下した.

・土石流入・土石流など鉄道事業者の管轄外に起因する 災害の割合が増加している。 その主な要因として, 短期間雨量の増加，台風上陸回数の増加などが考え られる。

自然災害に対する土木構造物の強化については，JR や大手民鉄などの大手では，法面対策や耐震強化など の防災投資を積極的に行っているが，経営難の中小民 鉄や第三セクター鉄道では防災投資の資金に乏しく防 災対策工事が進んでいない状況にある注1).

以上のことから，鉄道事業は風水害や地震・津波な ぞの自然災害を被る危険性があり，地球温暖化等を要 因として被災リスクが増加しつつあることが分かる. その危険性は，経営状況が厳しい中小民鉄や第三セク ター鉄道では特に深刻であると考えられる。

\section{(2) 自然災害による被害推計に関する先行研究}

自然災害リスクは，近年，その形成過程が工学的・理 学的に解明され，リスク評価の考え方が一般化されてき ている. 自然災害による被害想定額の算出方法も一般化 されつつあり，風水害については汇濫シミュレーション に基づく損害予測や「治水経済調査マニュアル（案）」

（国土交通省）》などの算定基準，地震については地震 動予測モデルに基づく損害予想 ${ }^{8}$ 队各地域の被害想定 （内閣府，地方公共団体等）などを挙げることができる. 鉄道構造物の自然災害リスク分析については，これま でに多くの工学的研究がある. 技術的課題として，数十

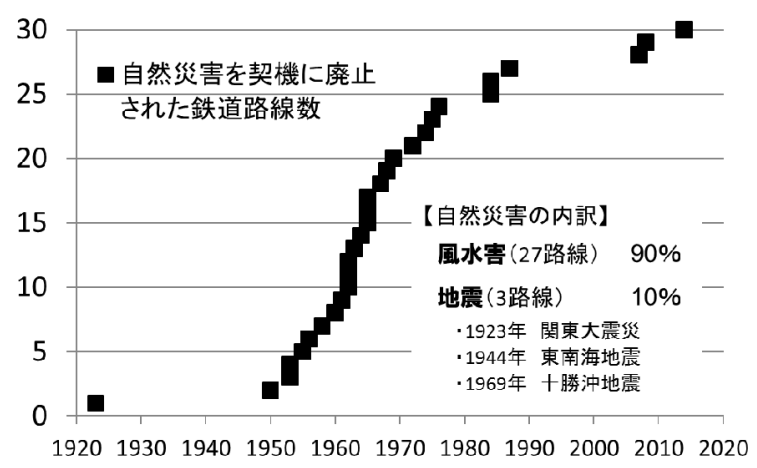

図-1 自然災害を契機に廃止された鉄道路線数（年代推移）

表-1 自然災害の一般的分類と鉄道被災実績例

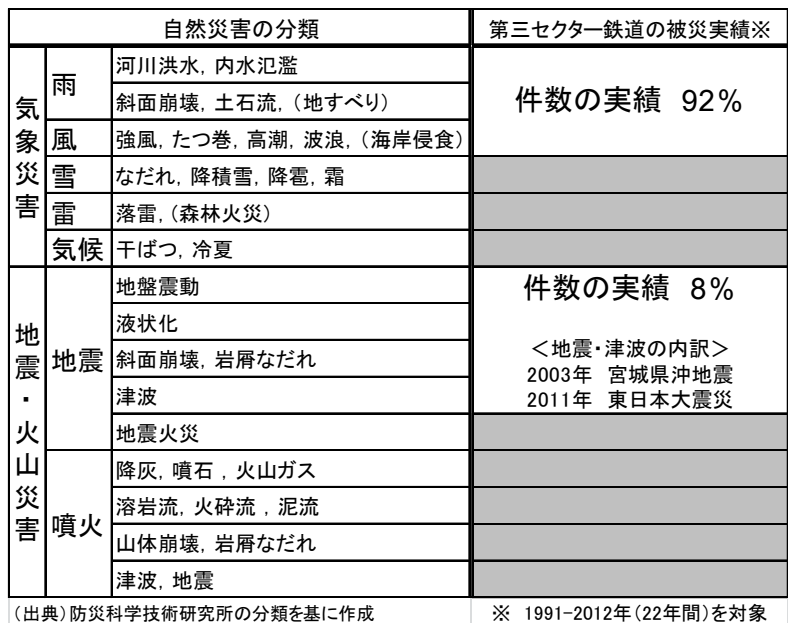

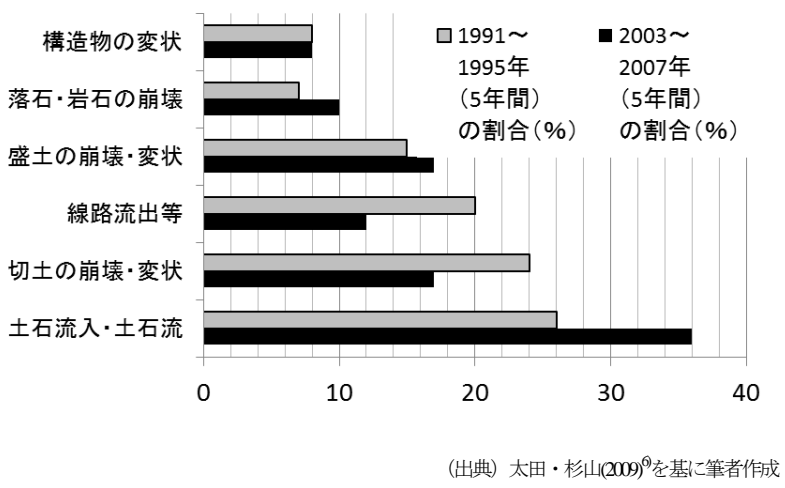

図-2 鉄道 $(\mathrm{JR})$ の自然災害種別の変化

～数百 $\mathrm{km}$ に及ぶ長大な鉄道の地震被害の工学的分析に ついは震源から鉄道沿線全体の地盤や構造物までを対 象にした分析が困難であったが，近年，先行研究9や鉄 道総合技術研究所 ${ }^{10}$ による実用的な解析手法が開発され つつある。

経済学の視点からは，大規模災害を想定した防災に係 る社会的費用便益分析や計量モデルなど自然災害リスク の経済評価手法の研究が蓄積されてきている ${ }^{11)}$.

こうした先行研究や実用手法の多くは，行政や大企業 
等を主な対象として，中長期的な防災投資や財務安定化 を主な目的としたものである. その分析手法の特徵は, 想定期間が数十年から数百年と長く, 損害額は既往最大 または想定最大である。つまり，伊勢湾台風や首都直下 地震のような超巨大災害を想定した工学的分析が多い.

なお，大規模自然災害による被害額算出の科学的根拠 については保険業法において法的規定がある。たとえば，

「保険業法施行規則第70条第2項等に関する大蔵省告 示」（平成10年6月8日大蔵省告示第232号）において工 学的モデルの使用を原則とし，工学的モデルがない自然 災害については過去の実績を統計的に処理した理論分布 に基づいたモデルを使用してもよい，と規定している.

\section{（3）本研究の基本的立場}

2.(2)で述べた先行研究から自然災害による被害想定に ついては既往最大または想定最大を前提とした工学的分 析が多いことが判明した。

鉄道事業に焦点を当てると, 本州 JR や大手民鉄など 大資本を有する企業では既往最大または想定最大を前提 とした自然災害リスク・ファイナンスが行われることが 多い 1,5.) しかしながら，中小民鉄や第三セクタ一鉄道 では，大規模災害に対しては公的補助に全面的に頼らざ るを得ないとの意見が多く 1,5)，保険料などの負担を軽 減したい一方で，災害復旧の資金不足を避けたいという 短期的かつ無駄のない資金調達に対するニーズが高い 5). すなわち, 発生頻度が比較的高い既往災害規模一の関心 が高い.また，鉄道各社の災害実績や経営状況を調べる と，鉄道会社ごとに災害特性と財務状況が大きく異なる ことも判明したら .

以上のことから, 経営状況が厳しく資本も乏しい鉄道 事業者が自然災害リスク・ファイナンスを実施する場合、 発生頻度が比較的高、既往災害規模を想定し，鉄道各社 の災害特性や財務状況を考慮し，積立金や保険などの複 数の資金調達手段を組合せて評価する科学的手法が必要 であると考えられる．こうした科学的手法は，鉄道事業 において, 体系的かつ明確な理論的根拠は, 筆者らが知 る限り見当たらない，そこで，本研究では，鉄道各社の 災害特性や財務状況を考慮し，来年度等の手元資金や保 険契約条件などの資金調達を数理統計的分析により推 計・検討するというアプローチをとった（図-3）.

\section{3. 破産確率の数理モデル}

\section{(1) 課題の設定}

調査の結果 ${ }^{12}$ 注 1)，鉄道事業者の主な関心事は，被災 したときに支払可能か，災害復旧に資金はいくら必要で， 複数の資金調達手法をどのように組合せたらよいかとい

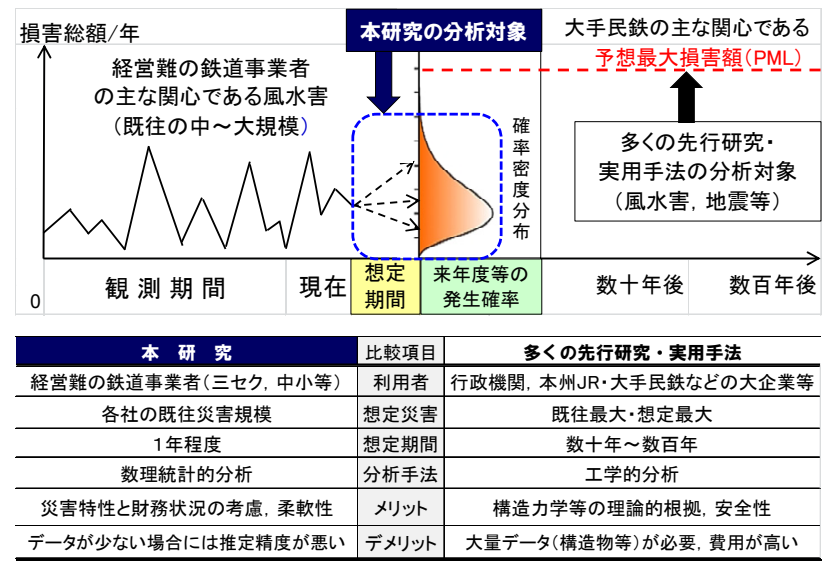

図-3 先行研究や実用手法に対する本研究の位置づけ5)

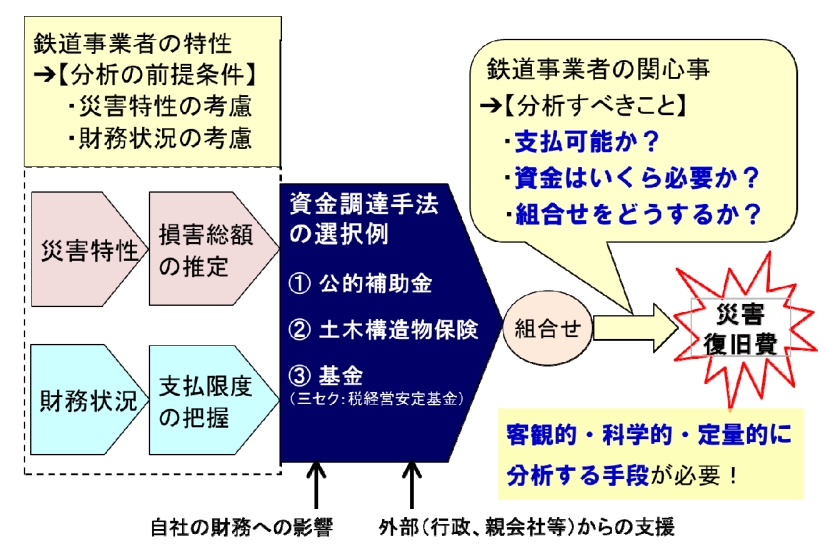

図-4 鉄道事業における災害復旧資金調達の課題 ${ }^{5)}$

うものであった．現在，中小民鉄や第三セクター鉄道等 では, 多くの場合, 不安を抱えながら経験的な勘により 資金調達が行われているようである。ここで難しいのは, 資金が少なければ破産の危険性が高まり，保険金などの 資金を増やせば保険料などの負担が増すという「バラン スの問題」である. この問題に対して，鉄道事業者の関 心やニーズ，各社の災害特性や財務状況の違いなどを考 慮すると，鉄道事業における災害復旧資金調達の課題は 図-4 のような体系となる。このことから本研究では, 図-4 の枠組みを基に資金調達を客観的・合理的・具体 的に分析する手段を課題として捉えた.

\section{（2）課題解決の基本フレーム}

災害復旧資金調達を具体化するために被災後の収支モ デルを考える（図-5）。一定期間（通常は年度）に被っ た自然災害による損害総額に対して使用可能な資金の総 和を「災害復旧資金」と言う。災害復旧資金は，図-5 のように手元資金と追加資金に分類できる．手元資金は 期首に支払手段として利用可能な自己資金であり，民鉄 


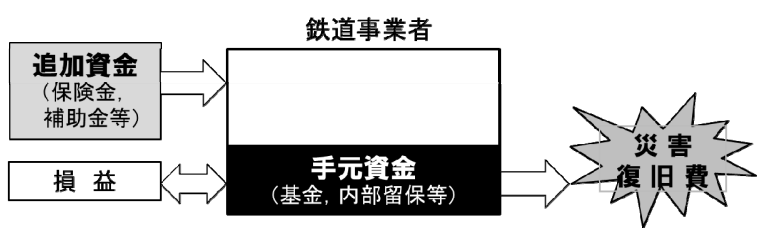

図-5＼cjkstart被災後の収支モデル5)

では利益剩余金，第三セクター鉄道では税経営安定基金 （以下，基金と略称する）などである．追加資金は期末 日までに手元資金以外に調達可能な資金であり，土木構 造物保険の保険金や公的補助金などである.「破産」と は，自然災害によって被災した一定期間の会計基準日 （通常は年度末）に災害復旧資金が不足することと定義 する.

鉄道事業者の主な関心は，年度単位の収支である．年 度収支を考えると，手元資金は期首に保有している資金 であり，第三セクタ一鉄道の場合には基金残高等に相当 する．年度単位の災害復旧費は，年度内に発生する自然 災害による損害総額である，その損害に対して，保険金 や補助金など外部から調達寸る資金の合計金額が追加資 金である、鉄道事業者の最大の関心事は災害復旧費を支 払えるか否かであるが，会計決算を行う期末時点で災害 復旧資金が不足する確率を「破産確率」と定義する.

以下，金融・保険分野を中心に発展してきたリスク理 論 (Risk Theory) ${ }^{12)}$ の先行研究を鉄道事業の自然災害リ スク・ファイナンスの問題解決に応用する.

\section{(3) 自然災害による損害総額の計量モデル}

損害総額の推定においては，損害発生の不確実性と， 損害金額の変動を数理的に捉える必要がある.そのため, ある鉄道会社において一定期間 $[0, t]$ に発生する自然災害 による損害総額を損害件数と損害金額の2つの要素に分 解し, 次の記号で表される確率変数として捉える.

$t:$ 時刻を表すパラメータ $(t \geqq 0)$

$N_{t}:$ 期間 $[0, t]$ に発生した自然災害による損害件数

$X_{i}:$ 期間 $[0, t]$ に発生した $i$ 番目の自然災害の損害金額 $\left(i=1,2, \cdots N_{t}\right)$

$S_{t}$ : 期間 $[0, t]$ に発生した自然災害による損害総額

このとき, 損害総額 $S_{t}$ を次のように表すことができる.

$$
S_{t}=X_{1}+X_{2}+\cdots+X_{N t}
$$

ここで，tを変動させることにより期間 $[0, t]$ に応じた損 害総額 $\left\{S_{t}\right\}_{t \geqq 0}$ を確率過程として捉えることができる.

ただし，確率論的なアプローチを行うために次の仮定 を設ける.

- $X_{1}, X_{2} \cdots$ 忙, 同一の分布に従う確率変数である.

・ $N_{t}, X_{1}, X_{2} \cdots$ は, 互いに独立である.
なお，一定期間 $[0, t]$ は，鉄道事業における年度単位の 業務慣習, 会計や保険などの法制度, データ管理区分等 を考慮すると1年間（1年度）を基本とすることが望まし いと考えられる. したがって, 通常は一定期間として1 年間を考え，添え字垺略し，次のように表す．

$$
S=X_{1}+X_{2}+\cdots+X_{N}
$$

このとき，SはNとXの複合分布に従うため, $S$ の分布 関数 $F_{s}(x)$, 期待值 $E(S)$, 分散 $V(S)$, 積率母関数 $M_{s}(t)$ は, 条 件付き確率を用いて次のように計算できる.

$$
\begin{aligned}
F_{S}(x) & =P(S \leq x)=\sum_{n=0}^{\infty} P(N=n) P(S \leq x \mid N=n) \\
& =\sum_{n=0}^{\infty} P(N=n) P\left(X_{1}+X_{2}+\cdots+X_{n} \leq x\right) \\
E(S) & =E_{N}[E(S \mid N)]=E_{N}[N E(X)]=E(N) E(X) \\
V(S) & =E_{N}[V(S \mid N)]+V_{N}[E(S \mid N)] \\
& =E_{N}[N V(X)]+V_{N}[N E(X)] \\
& =E(N) V(X)+V(N) E(X)^{2} \\
M_{S}(t) & \left.=E\left(e^{t s}\right)=E_{N}\left[E\left(e^{t S} \mid N\right)\right]=E_{N} \mid M_{X}(t)^{N}\right\rfloor \\
& =E_{N}\left[\exp \left(N \log M_{X}(t)\right)\right]=M_{N}\left[\log M_{X}(t)\right]
\end{aligned}
$$

ここで，損害件数過程 $\left\{N_{t}\right\}_{t \geqq 0}$ がポアソン過程であると き, 損害総額過程 $\left\{S_{t}\right\}_{t \geqq 0}$ は複合ポアソン過程と呼ばれる.

\section{（4）鉄道事業における破産確率モデル}

Lundbergモデル ${ }^{13)}$ を応用して，ある鉄道会社において 一定期間 $[0, t]$ に発生する自然災害による損害総額に対寸 る破産確率モデルを以下に定義する.

$u_{0}$ : 期間 $[0, t]$ 期首における鉄道事業者の手元資金

(例) 年度初の基金残高, 内部留保

$S_{t}$ : 期間 $[0, t]$ に発生した自然災害による損害総額

(損害件数 $N_{t}$ がパラメータ $\lambda t$ のポアソン分布に従

う複合ポアソン分布に従うと仮定する)

$P_{t}$ : 期間 $[0, t]$ 内に調達可能である追加資金

（例）保険金，補助金

$U_{t}$ : 期間 $[0, t]$ の期末における鉄道事業者の資金余力

このとき， $U_{t}$ は期末時点で㳄のように定式化できる.

$$
U_{t}:=u_{0}+P_{t}-S_{t}
$$

鉄道会社ごとに災害特性の差異が大きいため, $P_{t}$ は各 社の災害特性を反映した $E\left(S_{t}\right)$ に対応させることが望ま しい，そこで， $P_{t}$ を次のように定義する.

$c:$ 単位期間内に調達可能な追加資金

$\theta:$ 期待損害総額に対する追加資金割増率

$$
c:=(1+\theta) E(S)
$$




$$
P_{t}:=c t=(1+\theta) E(S) t
$$

このとき， $U_{t}$ は次のように表される.

$$
U_{t}=u_{0}+c t-S_{t}=u_{0}+(1+\theta) E\left(S_{t}\right) t-S_{t}
$$

以上のことから，期間 $[0, t]$ の期末における破産確率は， リスク・ファイナンスの関心事項である手元資金と追加 資金のパラメータである $u_{0}$ と $\theta$ に着目すると次のよう に定式化できる.

$$
\varepsilon\left(u_{0}, \theta\right):=P\left(U_{t}<0\right)=P\left[u_{0}+(1+\theta) E(S) t-S_{t}<0\right]
$$

\section{(5) 破産確率の一般的定理}

$U_{t}<0$ となることを破産としたが，破産時刻を表す確 率変数 $T$ を次式(12)で定義する.

$$
T:=\min \left\{t \mid U_{t}<0\right\}
$$

この破産時刻 $T$ を用いると，破産確率は次のように表 すこともできる.

$$
\varepsilon\left(u_{0}, \theta\right)=P(T<\infty)
$$

式(11)で定義した破産確率は Lundberg モデルを応用し たものであるが，3.(3)および 3.(4)の仮定の下で次の等式 が一般的に成り立つ ${ }^{14-16) . ~}$

$$
P\left(U_{t}<0\right)=\frac{\exp \left(-R u_{0}\right)}{E\left[\exp \left(-R U_{T}\right) \mid T<\infty\right]}
$$

ここで，式(14)右辺の $R$ は調整係数と呼ばれ，確率過 程 $\left\{\exp \left(-R U_{t}\right)\right\}_{t \geq 0}$ がマルチンゲールとなるような正の実数 である. すなわち， $R$ は任意の実数 $t$ に対して次の式を 満たす正の実数である.

$$
\left.E\left[\exp \left(-R U_{t}\right)\right) U_{\tau}\right]=\exp \left(-R U_{\tau}\right) \quad(t \geq \tau)
$$

3.(4)では $t \geqq 0$ を考えているため，上式において特に $\tau=0$ の場合に注目すれば,

$$
E\left[\exp \left(-R U_{t}\right)\right]=\exp \left(-R u_{0}\right)
$$

である、ここで，式(10)を代入し，式(6)を用いると，

$$
\begin{aligned}
E\left[\exp \left(-R U_{t}\right)\right] & =E\left[\exp (-R)\left\{u_{0}+c t-S_{t}\right\}\right] \\
= & \exp \left(-R u_{0}-R c t\right) \exp \left\{\lambda t\left(M_{X}(R)-1\right)\right\}
\end{aligned}
$$

であるから,

$$
\begin{gathered}
\exp \left(-R u_{0}-R c t\right) \exp \left\{\lambda t\left(M_{X}(R)-1\right)\right\}=\exp \left(-R u_{0}\right) \\
\therefore \lambda+c R=\lambda M_{X}(R)
\end{gathered}
$$

を満たさなければならない.

（6）鉄道事業における破産確率の計算式（風水害）

4.(3)および4.(4)で後述するように，全国の第三セクタ
一鉄道の過去22年分の被災実績データから確率分布を検 証した結果，風水害の 1 件あたりの損害金額 $X$ は指数分 布，風水害の1年あたりの損害件数Nはポアソン分布に 従うことが判明した. この検証結果を用いて鉄道事業に おける破産確率として次の定理を導くことができる.

定理３.(3)および3.(4)の破産確率モデルにおいて，自然 災害の個々の損害金額 $X$ がパラメータ $\mu$ の指数分布に従 うとき，一定期間 $[0, t]$ に発生する自然災害による損害総 額に対する破産確率は, 次の等式で表すことができる.

$$
\varepsilon\left(u_{0}, \theta\right)=P\left(U_{t}<0\right)=\frac{1}{1+\theta} e^{-\frac{\theta}{(1+\theta) \mu} u_{0}}
$$

\section{【証明】}

式(14)右辺を積率母関数を用いて変形すると

$$
P\left(U_{t}<0\right)=\frac{\exp \left(-R u_{0}\right)}{E\left[\exp \left(-R U_{T}\right) \mid T<\infty\right]}=\frac{\exp \left(-R u_{0}\right)}{M_{-U_{T}}(R \mid T<\infty)}
$$

となる．式(20)右辺の分母に着目し，破産直前の資金余 力を $U_{T}$-とし, 破産時刻 $T$ に発生する損害金額を $X$ と すると, $X$ はパラメータ $\mu$ の指数分布に従うので,

$$
\begin{aligned}
P\left(-U_{t}>y\right) & =\int_{0}^{\infty} f_{U_{T-}}(u) \frac{P(X>u+y)}{P(X>u)} d u \\
& =\int_{0}^{\infty} f_{U_{T-}}(u) \frac{\exp \left(-\frac{u+y}{\mu}\right)}{\exp \left(-\frac{u}{\mu}\right)} d u \\
& =\int_{0}^{\infty} f_{U_{T-}}(u) \exp \left(-\frac{y}{\mu}\right) d u=\exp \left(-\frac{y}{\mu}\right)
\end{aligned}
$$

となり， $T<\infty$ の条件下で- $U_{T}$ の分布はパラメータ $\mu$ の指 数分布に従う. したがって,

$$
M_{-U_{T}}(R \mid T<\infty)=\frac{1}{1-\mu R}
$$

である. 次に，調整係数 $R$ を方程式(18)より求める. 損 害金額 $X$ はパラメータ $\mu$ の指数分布に従うので,

$$
\begin{gathered}
c=(1+\theta) E(S)=(1+\theta) \lambda \mu \\
M_{X}(R)=\frac{1}{1-\mu R}
\end{gathered}
$$

より，式(18)は次のように変形できる.

$$
\begin{gathered}
\lambda+(1+\theta) \lambda \mu R=\lambda \frac{1}{1-\mu R} \\
\therefore R=\frac{\theta}{(1+\theta) \mu}
\end{gathered}
$$

したがって，式(20)に(22)と(25b)を代入して

$$
\begin{aligned}
\varepsilon\left(u_{0}, \theta\right)=P\left(U_{t}<0\right)= & (1-\mu R) \exp \left(-R u_{0}\right) \\
& =\frac{1}{1+\theta} e^{-\frac{\theta}{(1+\theta) \mu} u_{0}}
\end{aligned}
$$

となり証明完了である.

なお，本定理は金融・保険分野を中心に発展した数理 


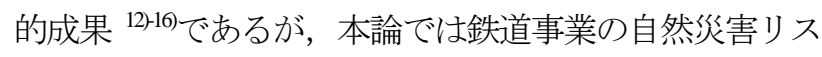
ク・ファイナンスに係るニーズや事業特性をふまえて応 用したものである.

以上のことから鉄道事業における自然災害による破産 確率の算出式を式(19)として導くことができる.この式 によって鉄道各社の災害特性と財務状況を反映した破産 確率を計算することできる，さらに，手元資金や追加資 金を変動させることによって破産確率に対寸る資金調達 の効果を数理的に分析できる.

\section{4. 損害総額に係る確率分布の実証分析}

\section{(1) 分析対象}

本論では，図-6に示寸全国の第三セクター鉄道におけ る平成3〜24（西暦1991～2012）年度の過去22年間の自 然災害による損害実績データを対象に損害総額に係る確 率分布の実証分析を行った，そのデータは第三セクター 鉄道等協議会と国土交通省鉄道局から御提供いただいた。

分析対象を第三セクター鉄道の損害実績にした主な理 由は，次のとおりである。

1) 第三セクター鉄道は，全国的に分散しており（図-6）, 気候や地形などの多様性も含めて自然災害に関する 全国的な傾向を調べるのに適していること.

2) 第三セクター鉄道では災害対策工事がほとんど行われ ていないので損害発生に係る母集団特性が経年的に ほぼ同一条件のまま保たれていること.

3) 第三セクター鉄道のほぼ全社が地震・津波を除く自 然災害対する土木構造物保険に継続的に団体加入し ており，保険金支払い等の被災履歴データが正確に 蓄積・管理されていること.

4) 鉄道会社一の災害復旧公的補助は鉄道軌道整備法（第 8条第4項）に基づいて行われているが，その補助実 績データが国土交通省鉄道局において蓄積・管理さ れていること.また，その補助実績の多くが第三セ クター鉄道であること。

5) 経営が厳しく資金余力に乏しい第三セクター鉄道で は自然災害リスク・ファイナンスのニーズが高く， 本研究による貢献が期待されていること.

以上のことから，全国の第三セクター鉄道を対象とし て鉄道事業の自然災害による損害総額に係る確率分布を 検証する．以下， 3.(3)で述べた一定期間として年度（1 年間）を考え，年間の損害発生件数 $N$ と損害 1 件あたり の損額金額Xの確率分布について実証分析を行う.

\section{（2）風水害と地震 ・津波の特性の違い}

鉄道事業における自然災害は，表-1に示寸実績から風 水害と地震・津波に大別できる. 第三セクター鉄道の過 去22年間（1991-2012年）の実績を基に，特性として発生

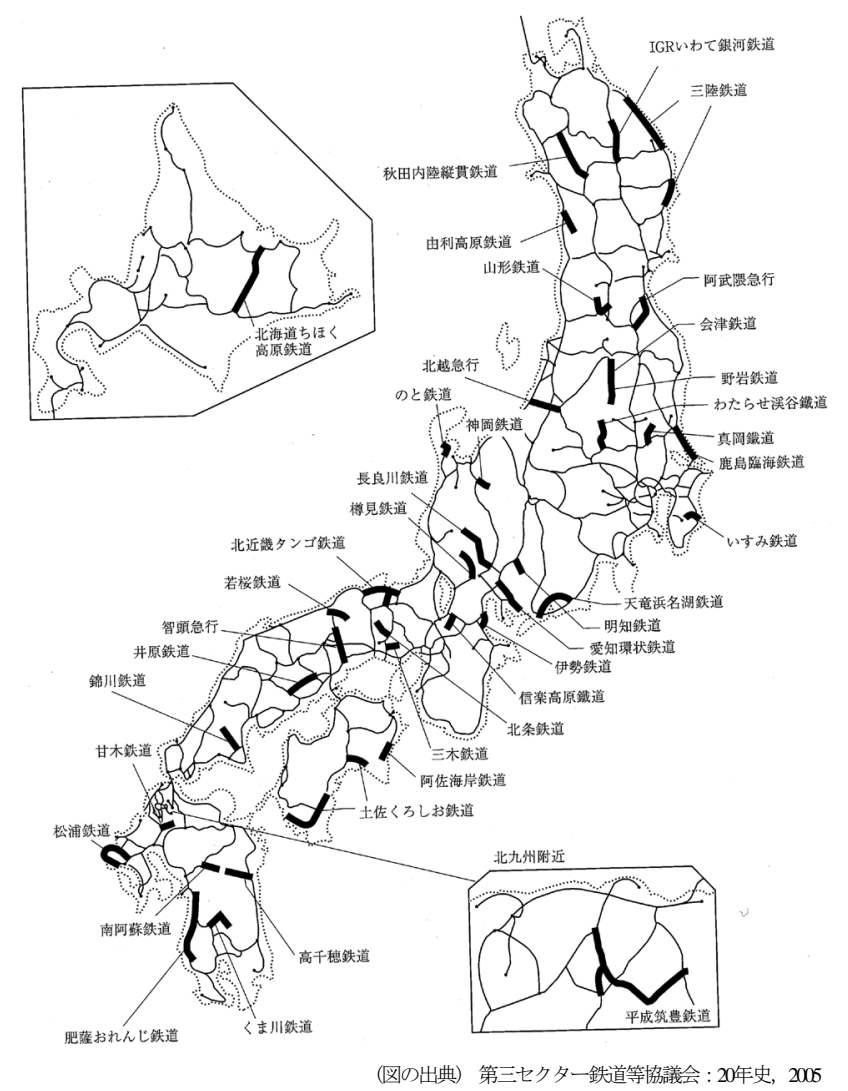

図-6 第三セクター鉄道の位置図 $\left(\right.$ 平成17年4月現在 ${ }^{177}$

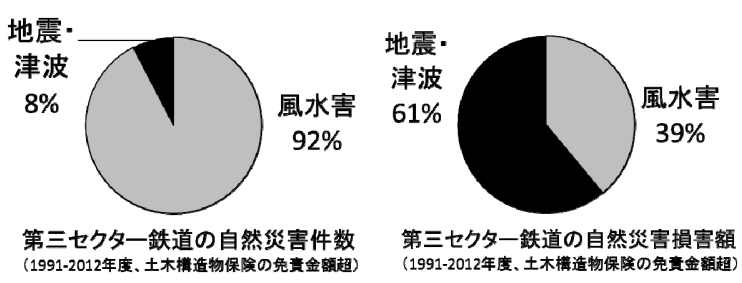

図-7 風水害と地震 - 津波の比較（件数，損害金額の合計）

件数年と損害金額の合計を比較すると図-7のとおりであ る. 図-7から地震・津波は，件数は $8 \%$ と少ないが損害 金額では61\%と風水害を損害金額を超える。つまり，地 震・津波は風水害と比べて発生頻度は少ないが1件あた りの損害金額が非常に大きいことが分かる。このことか ら, 地震・津波と風水害の確率的な特性は, 大きく異な ると考えられる.

地震・津波については，観測データが少なく，震源・ 地盤・地形などの地域特性に大きく依存するなどの理由 により発生件数や1件あたりの損害金額の確率分布を実 証分析することは困難であることから，以下では風水害 に対象として分析を行うこととした。

\section{（3）風水害1件あたりの損害金額の確率分布}

全国の第三セクター鉄道で1991～2012年度に発生した 土木構造物保険の支払保険金/件の実績は図-8のとおり 
表-2 風水害による損害金額/件の $\chi^{2}$ 適合度検定過程

\begin{tabular}{|r|c|c|c|c|}
\hline $\begin{array}{r}\text { 階級範囲※ } \\
\text { (万円/件) }\end{array}$ & \multicolumn{2}{|c|}{ 実 績 } & \multicolumn{2}{c|}{$\begin{array}{c}\text { 最尤推定量 } \\
\text { に基づく理論值 }\end{array}$} \\
\hline 以上 未満 & 実測度数 & 相対度数 & 理論値 & 理論確率 \\
\hline \hline $0-200$ & 3 & 0.032 & 8.492 & 0.091 \\
\hline $200-400$ & 12 & 0.129 & 7.717 & 0.083 \\
\hline $400-600$ & 11 & 0.118 & 7.012 & 0.075 \\
\hline $600-800$ & 8 & 0.086 & 6.372 & 0.069 \\
\hline $800-1000$ & 5 & 0.054 & 5.790 & 0.062 \\
\hline $1000-1200$ & 2 & 0.022 & 5.261 & 0.057 \\
\hline $1200-1600$ & 7 & 0.075 & 9.125 & 0.098 \\
\hline $1600-2000$ & 8 & 0.086 & 7.535 & 0.081 \\
\hline $2000-2400$ & 7 & 0.075 & 6.221 & 0.067 \\
\hline $2400-2800$ & 6 & 0.065 & 5.137 & 0.055 \\
\hline $2800-3400$ & 6 & 0.065 & 6.077 & 0.065 \\
\hline $3400-4200$ & 6 & 0.065 & 5.811 & 0.062 \\
\hline $4200-5400$ & 2 & 0.022 & 5.441 & 0.059 \\
\hline 5400-300000 & 10 & 0.108 & 7.009 & 0.075 \\
\hline \hline
\end{tabular}

表-3 風水害による損害金額/件の $\chi 2$ 適合度検定結果

\begin{tabular}{|l|c|c|}
\hline \multicolumn{1}{|c|}{ 検定基準 } & 数値 & 検定結果 \\
\hline \hline 適合度検定統計量 $\mathrm{T}$ & 14.969 & $\mathrm{P}(\mathrm{T} \geqq 14.969)=0.243$ \\
\hline$\chi 2(12)$ 分布の上側 $5 \%$ 点 & 21.026 & 帰無仮説は棄却されない. \\
\hline$\chi 2$ 2(12) 分布の上側 $1 \%$ 点 & 26.217 & 帰無仮説は棄却されない. \\
\hline
\end{tabular}

である。この分布形状から災害分野でよく見られる指数 分布が考えられる。そこで，1件あたりの損害金額Xが 母数 $\mu$ の指数分布に従うという帰無仮説 $H_{0}$ を

$$
H_{0}: P(X \leq x)=1-\exp \left(-\frac{x}{\mu}\right) \quad(x \geq 0)
$$

のように設定する. 未知の母数 $\mu$ 4.(5)で後述する最尤 推定量に基づいて損害金額の実績データから算出し, 理 論值と実績值を比較すると図-8のとおりである.

鹵無仮説 $H_{0}$ を $\chi^{2}$ 適合度検定により指数分布に従うか否 かの適合度を検定すると，表-2の計算過程を経て，表-3 の検定結果を得た。したがって，式(27)の帰無仮説 $H_{0} は$ 通常の有意水準では棄却されず，採択となる．つまり， データと理論分布（指数分布）の乘離は通常の偶然の変 動として説明できる程度のものであると考えられる.

なお，表-2の階級範囲0～200の実測度数3は，その理 論值8.492 と大きく乘離している. その原因として, 次 の2点が考えられる。こうした点を考慮すると，実際の 適合度はさらに良いと考えられる。

- 土木構造物保険の免責額以下の損害データは入手で きていない. その免責額の最低金額は100～300万円/ 件で推移してきた注1)ことから損害金額/件が0〜300万 円の実績データは欠損している.

・免責額超の損害であっても損害額が免責金額をわずか に超える場合には，保険金受取の翌年度から保険料 が值上がりすることから ${ }^{177}$ 注1)，鉄道事業者が保険金 を請求しなかった場合もありうる。
表-4 損害件数/年の $\chi^{2}$ 適合度検定計算過程

\begin{tabular}{|c|c|c|c|c|c|}
\hline \multicolumn{2}{|c|}{ 階級範囲※ } & \multicolumn{2}{|c|}{ 実 績 } & \multicolumn{2}{|c|}{$\begin{array}{c}\text { 最尤推定量 } \\
\text { に基づく理論値 }\end{array}$} \\
\hline 以上 & 未満 & 実測度数 & 相対度数 & 理論値 & 理論確率 \\
\hline 0 & 5 & 10 & 0.455 & $\begin{array}{l}7.552 \\
\end{array}$ & 0.343 \\
\hline 5 & 7 & 5 & 0.227 & 7.219 & 0.328 \\
\hline 7 & $\infty$ & 7 & 0.318 & 7.229 & 0.329 \\
\hline \multicolumn{2}{|c|}{ 合計 } & 22 & 1.000 & 22.000 & 1.000 \\
\hline \multicolumn{6}{|c|}{$\begin{array}{l}\text { (※)理論値が5以上となるように階級範囲を設定した. } \\
\text { (対象データ) } 1991 \text { 2012年度に第三セクター鉄道におおける } \\
\text { 自然災害による被災 (土木保険の免責金額超)の年間件数 }\end{array}$} \\
\hline
\end{tabular}

表-5 損害件数/年の $\chi^{2}$ 適合度検定結果

\begin{tabular}{|l|c|c|}
\hline \multicolumn{1}{|c|}{ 検定基準 } & 数値 & 検定結果 \\
\hline \hline 適合度検定統計量 $\mathrm{T}$ & 1.483 & $\mathrm{P}(\mathrm{T} \geqq 1.483)=0.223$ \\
\hline$\chi 2$ (1) 分布の上側 $5 \%$ 点 & 3.842 & 帰無仮説は棄却されない. \\
\hline$\chi 2$ 2(1)分布の上側 $1 \%$ 点 & 6.635 & 帰無仮説は裹却されない. \\
\hline
\end{tabular}

\section{（4）損害発生件数の確率分布}

一定期間に発生する損害件数がポアソン分布に従うこ とは，一定期間を分割した期間内（たとえば1日や1時 間）に損害が発生するか娝かという二項分布を考え，そ の期待值を一定に保ちながら分割期間を極小にした分布 がポアソン分布に収束することから数理的に証明できる

(ポアソン分布の小数の法則). その理論的根拠から, 全国の第三セクター鉄道を対象とした年間の損害発生件 数Nが母数入のポアソン分布に従うという帰無仮説 $H_{0} を$

$$
H_{0}: P(N=n)=e^{-\lambda} \frac{\lambda^{n}}{n !} \quad(n=0,1,2, \cdots)
$$

のように設定する. 未知の母数入を4.(5)で後述する最尤 推定量から求め, 損害件数の実績データから最尤推定值 を計算し，理論值と実績值を比較すると図-9のとおりで ある.

帰無仮説 $H_{0}$ を $\chi^{2}$ 適合度検定によりポアソン分布に従う か娝かの適合度を検定すると，表-4の計算過程を経て，

表-5の検定結果を得た。したがって，式(28)の帰無仮説 $H_{0}$ は通常の有意水準では萧却されず，採択となる．つま り, データと理論分布（ポアソン分布）の乘離は通常の 偶然の変動として説明できる程度のものであると考えら れる.

なお，4.(3)で述べたように免責金額以下の損害につい てはデータが久損しており，免責額超の損害であっても 損害額が免責額をわずかに超えるような場合には保険金 請求が行われていなかった場合もありうることを考慮す ると，実際の適合度はさらに良いと考えられる。

\section{(5) データ制約下の最尤推定量}

4.(3) および4.(4)より式(27)と式(28)で表される確率分布 の未知の母数 $\lambda, \mu$ を被災実績データから推定できれば, 3.(3)で述べたように損害総額を複合ポアソン分布として 計量することができる.ただし，土木構造物保険の実績 


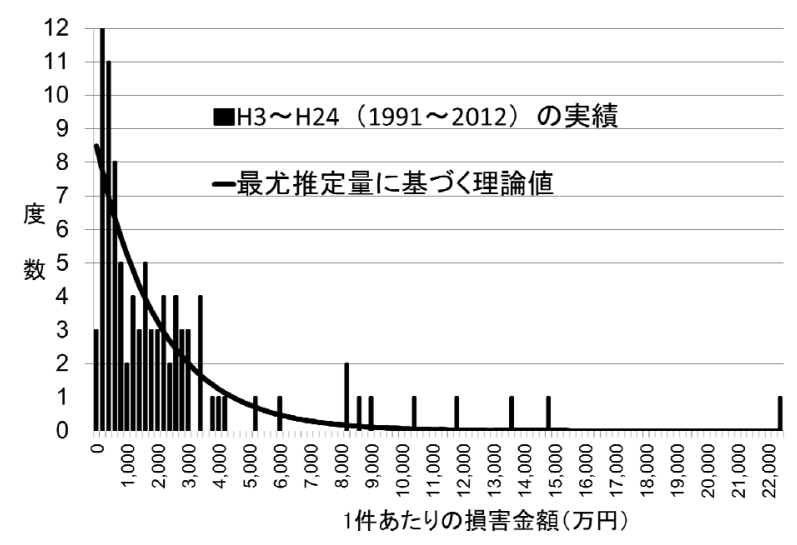

図-8 風水害による損害金額/件の実績と理論值 (対象:全国の第三セクタ一鉄道)

データには免責額超という制約がある（保険金の支払限 度という制約もあるが，その損害実績は既知である）。

したがって，免責額以下の損害に関する実績データは不 明である.こうしたデータの制約下でも最尤推定量を求 められる理論的根拠について述べる.

まず，式(28)の指数分布（確率密度関数 $f_{x}(x)$ ) に従う 1 件あたりの損害金額Xの最尤推定量について考える。土 木構造物保険の免責金額が $\alpha$ の場合， $\alpha$ を超える損害額 が発生したという条件下での損害額の条件付き確率密度 関数を $g(x)$ とすると，

$$
\begin{aligned}
g(x) & =f_{X \mid X>\alpha}(x)=\frac{\frac{\partial}{\partial x} P(X \leq x \cap X>\alpha)}{P(X>\alpha)} \\
= & \frac{\frac{1}{\mu} \exp \left(-\frac{x}{\mu}\right)}{\exp \left(-\frac{\alpha}{\mu}\right)}=\frac{1}{\mu} \exp \left(-\frac{x-\alpha}{\mu}\right) \quad(x>\alpha)
\end{aligned}
$$

となる．このとき $i$ 件目の損害額 $X_{i}$ に対応する土木構造 物保険の免責金額を $\alpha_{i}$ ，全損害件数を $m$ とすると，尤度 関数は

$$
L(\mu)=\prod_{i=1}^{m} g\left(x_{i} ; \mu\right)=\prod_{i=1}^{m} \frac{1}{\mu} \exp \left(-\frac{x_{i}-\alpha_{i}}{\mu}\right)
$$

となるので，その対数尤度方程式は，

$$
\frac{\partial}{\partial \mu} \log L(\mu)=-\frac{m}{\mu}+\frac{1}{\mu^{2}} \sum_{i=1}^{m}\left(x_{i}-\alpha_{i}\right)=0
$$

となる.したがって，最尤推定值は

$$
\widehat{\mu}=\frac{1}{m} \sum_{i=1}^{m}\left(x_{i}-\alpha_{i}\right)
$$

となり，既知である土木構造物保険の支払保険金デー夕 から求めることができる. 寸なわち，免責額以下の損害 実績データが無くても最尤推定值を数理的に求めること ができる. 4.(3)では式(32)を基に最尤推定值 $\hat{\mu}=2593$ 万

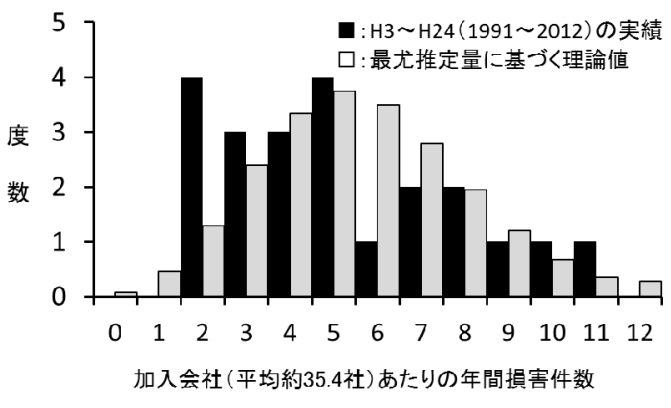

図-9 損害発生件数/年の実績と理論伹 (対象:全国の第三セクター鉄道)

円/件（標準誤差377，95\%信頼区間 [1845, 3341]）を求 め，式(27)により図-8に示寸理論值を算出した.

次に, 式(28)のポアソン分布に従う年間損害件数 $N$ の 最尤推定量について考える. 損害件数についても土木構 造物保険の免責金額以下の実績は不明である。そこで, 実績データから免責金額以下の災害件数を推定する必要 がある。いま，土木構造物保険の免責金額 $\alpha$ の年間保険 金支払件数Kをとすると，

$$
E(K)=P(X>\alpha) E(N)
$$

であり, 推定したい母数入については,

$$
\lambda=E(N)
$$

なので，母数入の最尤推定量は，

$$
\hat{\lambda}=\frac{E(K)}{P(X>\alpha)}
$$

より求めることができる.

なお，観測データが22年分と少ないこともあり，4.(4) では損害件数の実態をなるべく正確に反映するため，土 木構造物保険の支払保険金デー夕の他に，鉄道軌道整備 法に基づく公的補助金を受けたが土木構造物保険の保険 金を受けていない被災実績なども含めて式(35)に基づき $E(K)$ として免責額を超える被災件数の全体平均， $\alpha$ を免 責額の全体平均として $\lambda$ の最尤推定值 $\hat{\lambda}=5.59$ 件/年（標 準誤差0.62，95\%信頼区間 $[4.09,6.67])$ を求め, 式(28) により図-9に示す損害件数の理論值を算出した.

以上のように，年間損害件数がポアソン分布，1件あ たりの損害額が指数分布に従うとき，土木構造物保険の 支払条件下の実績データの情報だけで最尤推定量を求め ることができる.

なお，最尤推定量には，一致性，漸近正規性，漸近有 效性など推定において望ましい特性があるので18)，実績 データが多くなるほど推定精度は向上寸るものと考えら れる. 


\section{5. 結論}

\section{(1) 主要な成果}

わが国の多くの鉄道事業者（中小民鉄，第三セクター 鉄道等）は，経営状況が厳しく資本も乏しい。こうした 鉄道事業者にとって，一時期にきわめて多額の支払いが 必要となる自然災害復旧の資金調達は存亡に係る切実な 経営課題である. 鉄道の廃止は沿線地域の社会経済にも 多大な影響を与えるため, 鉄道事業の自然災害リスク・ ファイナンスは社会的にも重要な課題である.

本論は，2.(3)や3.(1)で述べた多くの鉄道事業者の現場 ニーズに応えるため, 鉄道各社の災害特性や財務状況を 考慮し，毎年行われる手元資金や保険契約などの資金調 達に係る経営判断の数理的根拠として破産確率を提案し， 被災実績データから実証した確率分布を用いて破産確率 を数式化した. 本論により得られた具体的な成果を整理 すると以下のとおりである.

1) 3. で金融・保険分野を中心に発展してきたリスク理 論を鉄道事業の自然災害リスク・ファイナンスに応 用し，一定期間において損害件数がポアソン分布に 従い，1件あたりの損害金額が指数分布に従うときの 破産確率を体系的に示した.

2) 4.(3)で第三セクター鉄道の自然災害による損害実績 データを基に風水害による1件あたりの損害金額が指 数分布に従うことを統計的に実証した.

3） 4.(4)で第三セクター鉄道の自然災害による損害実績 データを基に風水害による1年間の災害件数がポアソ ン分布に従うことを統計的に実証した。

4) 鉄道事業の自然災害による損害実績データの多くは 土木構造物保険の支払保険金であり各社・各年で免 責金額や支払限度が変動するなどの制約があるが，

4.(5)で入手可能な実績データを基に最尤推定量を求 められることを示した。

5) 以上より, 風水害については, 破産確率の式(19)之 母数パラメータ推定 (4.(5)) により算出できること を示した。なお, 風水害は, 路線廃止の契機となっ た災害件数の9割，第三セクタ一鉄道の被災件数実績 の $92 \%$ を占めるなどの理由から，鉄道事業者にとっ て量的には圧倒的な自然災害リスクである。

\section{(2) 今後の研究課題}

本論は鉄道事業の自然災害全般を対象として研究を進 めてきたが, 風水害と地震・津波の確率的特性が大きく 異なること (図-7参照)，地震・津波のデータが非常に 少ないことなどの理由により風水害を対象に確率分布の 検証を行った，その結果，図-10に示寸ように風水害を 対象にした損害総額と破産確率の算出は可能となった.

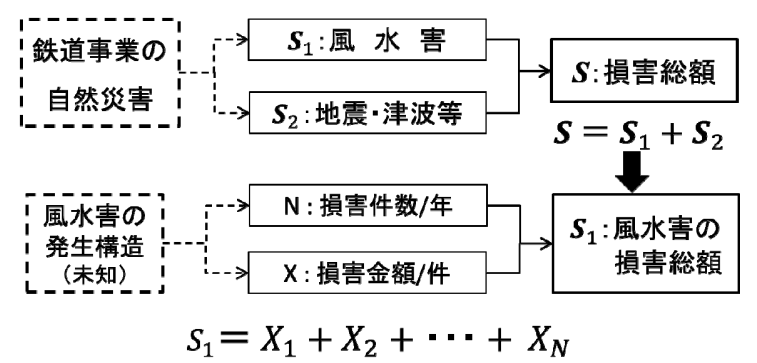

図-10 自然災害と損害総額の関係

今後の発展性として，地震・津波などの損害も破産確 率に組み込み，全ての自然災害を対象としたリスク・フ アイナンスに拡張することが考えられる．地震・津波に よる鉄道構造物の工学的な被害推計は技術的に向上しつ つあるが，地震・津波被害も反映した破産確率について も今後の研究課題である.

さらに，実務要件等を考慮した条件設定や分析手法の 改良を行う必要がある.

謝辞 : 本研究に際し，国土交通省鉄道局，第三セクター 鉄道等協議会, 複数の鉄道会社様をはじめ多くの方々か ら情報提供ならびに御指導を賜った．本研究は運輸政策 研究所の研究として行った研究成果の一部である. 研究 の過程で運輸政策研究所の杉山武彦所長をはじめ運輸政 策研究機構の多くの方々から貴重な助言や支援を頂戴し た.本論文を査読された方には有益な御指摘をいただい た. ここに記して深く感謝申し上げます。

注

注 1） 2014〜2015 年に中小民鉄, 第三セクタ一鉄道, 第三セクター鉄 道等協議会にヒアリング調査（5回）を行った.

\section{参考文献}

1) 内田傑, 平田輝満, 松野由希, 伊鍾進, 未吉徹也： 交通施設の災害復旧に対するリスクファイナンスと 公的負担制度に関寸る現状と課題, 運輸政策研究, Vol. 12, No. 2, pp. 66-72, 2009.

2) 森地茂: 社会資本のリスク対応の制度的課題, 土木 学会誌, Vol. 94, No. 8, p. 38, 2009.

3) 野澤和行, 松田清宏, 森地茂: 交通施設の災害復旧 に対するリスクマネジメントと公的負担制度に関す る研究, 運輸政策研究, Vol. 13, No. 3, pp. 85-92, 2010.

4) 平田輝満, 野澤和行, 佐々木慧, 未吉徹也: 交通施 設の災害復旧に対するリスクマネジメントと公的負 担制度に関する研究, 運輸政策研究, Vol. 14, No. 3, pp. 67-72, 2010.

5) 大堀勝正：鉄道事業における自然災害リスク・ファ イナンスに関する研究一破産確率とその活用, 運輸 政策研究, Vol. 18, No. 2, pp. 69-73, 2015.

6) 太田直之, 杉山友康: 災害の推移亡今後の防災, 日 本鉄道施設協会誌，2009.6. 
7）国土交通省河川局：治水経済調査マニュアル（案）， 2005.

8）たとえば，兼森孝：災害リスクのアセスメント（地 震リスクの定量化），多々納裕一・高木朗義編，「防 災の経済分析」勁草書房, pp. 49-71, 2005.

9）たとえば, 大峯秀人, 吉川弘道, 矢代晴実, 大滝 健：リスクファイナスのための線状施設の地震リス ク評価, 土木学会論文集 F6, Vol. 67, No. 1, pp. 14-26, 2011.

10）鉄道総合技術研究所：鉄道地震災害シミュレータの 開発(http://www.rtri.or.jp/press/pdf/20150713.pdf), 2015.

11）たとえば，多々納裕一，高木朗義編：防災の経済分 析一リスクマネジメントの施策と評価, 勁草書房, 2005.

12) たとえば, McNeil, A. J., Frey, R. and Embrechts, P. : Quantitative Risk Management : Concepts, Techniques and
Tools, Princeton University Press, 2005. (邦訳 ; 塚原英 敦他訳：定量的リスク管理，共立出版，2008.)

13) Lundberg, F. : Approximerad Framställning av Sannolikehetsfunktionen, Återförsäkering av Kollektivrisker, Almqvist \& Wiksell, Uppsala, 1903.

14）たとえば, Stuart, A. K., Harry, H, P. and Gordon, E. W. : Loss Models from Data to Decisions, 3rd editon, Wiley, 2008.

15) Soren, A. and Hansjorg, A. : Ruin Probabilities, 2nd edition, World Scientific, 2010.

16）岩沢宏和：リスク・セオリーの基礎，培風館，2010.

17) 第三セクター鉄道等協議会 : 20 年史, 2005.

18) たとえば, 柳川堯 : 統計数学, pp. 133-139, 近代科学 社, 1990 .

\section{RUIN PROBABILITY ON NATURAL DISASTER RISK FINANCE IN THE RAILWAY BUSINESS}

\section{Katsumasa OHORI and Shigeru MORICHI}

Risk financing for natural disasters is an important management issue in the railway business because of frequent natural disasters such as typhoons and earthquakes in Japan. In this paper, we propose the mathematical model of ruin probability on natural disaster risk finance in the railway business. The model is the quantitative analytical method of the suitable risk finance according to the financial situation and the natural disaster risk peculiar to the respective railways. Furthermore, we also report the statistical evidence based on the restoration expense of losses by natural disasters. 